Cezary Szydtowski

Uniwersytet Lódzki

\title{
Rola audytu wewnętrznego w ocenie wydatków samorządów miejskich
}

\section{THE ROLE OF INTERNAL AUDIT IN THE EVALUATION OF URBAN LOCAL GOVERNMENT EXPENDITURES}

Artykut przedstawia rolę oraz zadania audytu wewnętrznego w ocenie wydatków publicznych $w$ wybranym obszarze na przykładzie samorzqdów miejskich $w$ Łodzi, Piotrkowie Trybunalskim oraz Skierniewicach. W toku badań ustalono m.in., że audyt wewnętrzny poprzez swoje zadania przyczynia sie do racjonalniejszego wydatkowania środków finansowych z budżetu miasta na działania administracji publicznej. Ponadto wykazano również, że audyt wewnętrzny jest pomocnym narzędziem $w$ dbaniu o ponoszenie uzasadnionych wydatków przez jednostki sektora finansów publicznych. Ocena oraz monitorowanie wydatków jest powinnościq władzy publicznej $w$ celu zapewnienia racjonalnej gospodarki finansowej danej jednostki samorzadu terytorialnego.

Celem artykulu jest przedstawienie audytu wewnętrznego jako istotnego narzędzia wsparcia organów miasta w ocenie wydatków gmin miejskich w wybranym obszarze. Na potrzeby niniejszej publikacji jako przykład do analizy wybrano jednostki samorzqdu terytorialnego z województwa tódzkiego tj. miasta na prawach powiatu.

$W$ niniejszym artykule jako metody badawcze wykorzystano studium przypadku, metode analityczna, metodę wnioskowania oraz metodę badania dokumentów. Do przeprowadzenia niezbędnych analiz wykorzystano materiaty udostęniane przez badane podmioty oraz dane dostępne w rejestrach publicznych, gromadzonych przez uprawnione do tego instytucje.

Słowa kluczowe: finanse publiczne, audyt wewnętrzny, samorząd terytorialny JEL Codes: H-72, H-83

\section{Wprowadzenie}

Finanse samorządu terytorialnego powinny być wydatkowane racjonalnie, zasadnie oraz adekwatnie do poziomu dochodów i ogólnego stanu środków finansowych w budżecie danej jednostki. Racjonalne wydatkowanie środków publicznych ma miejsce gdy jest celowe, oszczędne, terminowe, wynika $\mathrm{z}$ uchwały budżetowej oraz jest zgodne $\mathrm{z}$ przyjętymi przez jednostkę planami finansowymi. ${ }^{1}$ Nie jest to możliwe bez sprawowania nadzoru i kontroli nad tym procesem. Przydatnym narzędziem w tym zakresie jest audyt wewnętrzny, który poprzez swoje zadania dostarcza poszczególnym interesariuszom informacji i wskazówek dotyczących sytuacji finansowej jednostki samorządu terytorialnego. Prawidłowość, zasadność i racjonalność wydatkowania środków

\footnotetext{
1 J. Szołno-Koguc, Racjonalność wydatków publicznych a realizacja budżetowej zasady jedności [w:] Głuchowski, J., Pomorska, A., Szołno-Koguc, J. (red.), Ekonomiczne i prawne problemy racjonalizacji wydatków publicznych, Tom 1: Racjonalizacja wydatków publicznych uwarunkowania $i$ instrumenty, Uniwersytet Marii Curie - Skłodowskiej, Lublin, 2005 r., s. 140.
} 
publicznych jest kluczowa dla procesu realizacji budżetu danej jednostki samorządu terytorialnego. Każdy wydatek powinien być zgodny z planem budżetu na dany rok oraz odpowiednio udokumentowany i zaewidencjonowany w systemach finansowo księgowych jednostki. Ocena wydatków może obejmować różny zakres w zależności od celów realizowanego audytu. ${ }^{2}$ Rolą audytu wewnętrznego jest m.in. przeprowadzenie oceny planowania i realizacji budżetu jednostki. Zatem audyt wydatków jest jednym $z$ kluczowych obszarów do prowadzenia oceny funkcjonowania jednostki sektora finansów publicznych przede wszystkim w zakresie realizacji budżetu. ${ }^{3}$ Każdorazowo audyt wewnętrzny w wybranym obszarze wydatków powinien obejmować poszczególne wydatki ekwiwalentne i redystrybucyjne. Warto wspomnieć, że końcowa ocena audytora w zakresie poszczególnych wydatków powinna uwzględniać szereg ograniczeń sektora publicznego, które dotyczą choćby polityki zakupowej czy też zasad budżetowania. ${ }^{4}$

Samorząd terytorialny realizuje wiele zadań własnych i zleconych z zakresu administracji rządowej $\mathrm{w}$ ramach, których świadczy usługi publiczne na rzecz danej społeczności. Obowiązujący w Polsce system administracji publicznej, wyznaczył administracji samorządowej bardzo ważną rolę służebną na rzecz danej wspólnoty (regionalnej lub lokalnej). Największy wpływ na bieżące życie każdego mieszkańca ma działalność samorządu terytorialnego na szczeblu gminy (w tym miasta na prawach powiatu). Gmina zapewnia swojej społeczności lokalnej usługi publiczne bez których nie jest możliwe bieżące funkcjonowanie danej społeczności i rozwój społeczno - gospodarczy. Realizacja tych zadań nie jest możliwa bez odpowiedniej infrastruktury technicznej, zasobów kadrowych oraz środków finansowych.

Wykonywanie przez gminę jej ustawowych zadań wymaga ponoszenia wydatków na ich realizację $w$ tym także związanych $z$ funkcjonowaniem administracji publicznej. Realizacja zadań przez samorząd gminny finansowana jest z danin publicznych, na które składają się poszczególni mieszkańcy zgodnie z obowiązującymi przepisami prawa $\mathrm{w}$ tym zakresie. W związku $\mathrm{z}$ tym bardzo istotne jest, aby środki finansowe zgromadzone w budżecie każdej jednostki samorządu terytorialnego były wydatkowane zgodnie z prawem i w zakresie niezbędnym do skutecznej realizacji zadań. Prowadzenie racjonalnej gospodarki finansowej (w tym zrównoważenia budżetu gminy w zakresie dochodów i wydatków) wymaga od jej kierownictwa sprawowania adekwatnego do potrzeb nadzoru nad dochodami i poszczególnymi wydatkami z jej budżetu. ${ }^{5}$ Bardzo ważne jest przy tym prowadzenie weryfikacji wydatków pod kątem możliwości ich sfinansowania, czyli pokrycie danego wydatku z dochodów do budżetu gminy. ${ }^{6}$

Jednym z obszarów działania samorządu, który generuje znaczne koszty działania każdej gminy są wydatki na administrację publiczną. Wydatki w powyższym obszarze budzą znaczne zainteresowanie poszczególnych interesariuszy w gminie (mieszkańców, przedsiębiorców itd.). W związku $\mathrm{z}$ tym istotne jest, aby również $\mathrm{w}$ tym obszarze racjonalnie wydatkowano środki publiczne $\mathrm{z}$ budżetu gminy. Istotne zadania $\mathrm{w}$ tym zakresie realizuje audyt wewnętrzny, który dokonuje oceny poszczególnych obszarów

\footnotetext{
2 J. Pfaff, Rewizja finansowa, Uniwersytet Ekonomiczny w Katowicach, 2011 r. s. 72-77.

3 A. Żabka, Efficiency of budget expenditure inthe process of creating framework conditions for local development. Planing and evaluation, Wyższa Szkoła Finansów i Prawa, Bielsko - Biała, 2017 r., s. 56-59.

${ }^{4}$ J. E. Stiglitz, Ekonomia sektora publicznego, PWN, Warszawa 2004 r., s. 235-237.

${ }^{5}$ M. Gazda, O procesie racjonalizacji wydatków publicznych, Ruch Prawniczy, Ekonomiczny i Socjologiczny, VOL 78, NR 1 (2016), Uniwersytet Adama Mickiewicza w Poznaniu, s. 169-179.

${ }^{6}$ M. Dylewski, B. Filipiak, M. Gorzałczyńska-Koczkodaj, Finanse samorzadowe. Narzędzia, decyzje, procesy, PWN, Warszawa 2006 r., s. 184-186.
} 
działania danej jednostki sektora finansów publicznych. Ocena audytu wewnętrznego obejmuje wszystkie aspekty i obszary działania danej jednostki ze szczególnym zwróceniem uwagi na ocenę realizacji jej budżetu. Zatem audyt wydatków jednostki samorządu terytorialnego na funkcjonowanie samorządowej administracji publicznej stanowi istotny obszar, który zasługuje na analizę oraz ocenę.

\section{Audyt wewnętrzny w jednostkach sektora finansów publicznych}

Zasady funkcjonowania audytu wewnętrznego oraz obligatoryjny obowiązek jego wdrażania w poszczególnych jednostkach sektora finansów publicznych zostały uregulowane w ustawie z dnia 27 sierpnia 2009 r. o finansach publicznych. Ustawa określiła również niezbędne kwalifikacje i kryteria jakie musi spełnić osoba wykonująca zawód audytora wewnętrznego. Głównym celem audytu wewnętrznego jest usprawnienie systemu sprawowania nadzoru i kontroli nad działalnością danej jednostki, szczególnie w zakresie gospodarki finansowej. Szczegółowe zasady prowadzenia audytu wewnętrznego w jednostkach sektora finansów publicznych, raportowania o jego wynikach i zasady sprawozdawczości w tym zakresie zostały określone w Rozporządzeniu Ministra Finansów z dnia 4 września 2015 r. ${ }^{7}$ Audyt wewnętrzny w Polsce jest realizowany zgodnie z międzynarodowymi zasadami, wytycznymi oraz metodami pracy. Przyczynił się do wielu zmian w jednostkach sektora finansów publicznych, które obejmowały m.in. wdrożenie procesu identyfikacji i zarządzania ryzykiem, zwiększenie nadzoru i kontroli nad realizacją zadań, usprawnienie poszczególnych procesów objętych audytem itd.

Audyt wewnętrzny zgodnie z treścią art. 272 ustawy o finansach publicznych z 2009 r. jest „działalnościq niezależna $i$ obiektywna, której celem jest wspieranie ministra kierujacego działem lub kierownika jednostki $w$ realizacji celów $i$ zadań przez systematyczna ocene kontroli zarzadczej oraz czynności doradcze, ocena dotyczy w szczególności adekwatności, skuteczności i efektywności kontroli zarzqdczej $w$ dziale administracji rzadowej lub jednostce". ${ }^{8}$ Warto wspomnieć, że kierownicy jednostek sektora finansów publicznych w efekcie wprowadzenia audytu wewnętrznego uzyskali nowy instrument wspomagający procesy podejmowania decyzji, zarządzania ryzykiem oraz gospodarowania finansami będącymi w dyspozycji organu władzy publicznej. Audyt wewnętrzny z uwagi na swoją niezależność i brak zaangażowania w bezpośrednią działalność operacyjną jednostki przedstawia obiektywną ocenę badanego obszaru i proponuje jego usprawnienie. Audytorzy wewnętrzni w swojej pracy muszą kierować się międzynarodowymi standardami pracy oraz zasadami kodeksu etyki audytora wewnętrznego. Standardy stanowią dla audytorów wewnętrznych podstawowe wytyczne, określające sposób prowadzenia przez nich swoich czynności oraz zadań im przypisanych, w sposób zapewniający wysoką jakość wykonywanej pracy, obiektywizm, niezależność oraz profesjonalizm. Zachowanie obiektywnej, bezstronnej oceny audytowanego procesu zapewnia kierownikowi jednostki sektora finansów publicznych rzetelny ogląd sytuacji podmiotu w zakresie gospodarki finansowej.

Głównym celem audytu wewnętrznego jest wsparcie kierownictwa jednostki poprzez systematyczną ocenę poszczególnych obszarów działania danej instytucji, przy jednoczesnym uwzględnieniu oceny potencjalnych ryzyk. Ryzyko można zdefiniować jako

\footnotetext{
${ }^{7}$ Rozporzq̨dzenie Ministra Finansów z dnia 4 września 2015 r. w sprawie audytu wewnętrznego oraz informacji o pracy $i$ wynikach tego audytu (tj. Dz. U. z 2018 r., poz. 506).

${ }^{8}$ Ustawa z dnia 27 sierpnia 2009 r. o finansach publicznych (tj. Dz. U. z 2019 r., poz. 869), art. 272.
} 
„możliwość wystapienia zdarzenia, które będzie miało wplyw na organizację. Istnieja dwa źródta ryzyka: zagrożenie bezpośrednie (zdarzenie szkodliwe), które powoduja, że cele nie zostana osiagnięte, szanse (zdarzenia korzystne), które daja możliwość skuteczniejszego osiagnięcia celów". Audytorzy podczas swojej pracy obejmującej głównie analizę i weryfikację dokumentacji źródłowej (będącej podstawą do wydania oceny w badanym obszarze) muszą każdorazowo identyfikować oraz szacować potencjalne ryzyka występujące w tym obszarze. Analiza ryzyka w zakresie badanego obszaru musi odnosić się również do wdrożonego przez kierownictwo systemu kontroli wewnętrznej. ${ }^{10}$ Audytorzy wewnętrzni podczas prowadzenia czynności audytowych w zakresie realizowanego audytu (np. dochodów lub wydatków), zobligowani są do weryfikacji i oceny funkcjonującego w jednostce systemu kontroli zarządczej. ${ }^{11}$ Kontrola zarządcza to „ogót działań podejmowanych dla zapewnienia realizacji celów $i$ zadań $w$ sposób zgodny $z$ prawem, efektywny, oszczędny i terminowy. Celem kontroli zarzadczej jest zapewnienie $w$ szczególności: zgodności działalności z przepisami prawa oraz procedurami wewnętrznymi; skuteczności i efektywności działania; wiarygodności sprawozdań; ochrony zasobów; przestrzegania $i$ promowania zasad etycznego postepowania; efektywności $i$ skuteczności przeplywu informacji; zarzadzania ryzykiem". ${ }^{2}$ Kontrola bądź audyt wydatków jest zalecana przez ekspertów np. Banku Światowego narzędzie do prawidłowego zarządzania budżetem przez samorządy. ${ }^{13}$

Audytorzy wewnętrzni realizując swoje zadania oceniają m.in. proces gromadzenia środków budżetowych, systemy egzekucji należności, proces planowania budżetu jednostki oraz jego realizację w poszczególnych obszarach. Zajmują się również weryfikacją prawidłowego ewidencjonowania operacji finansowych $\mathrm{w}$ systemach finansowo - księgowych. Audyt wewnętrzny prowadząc ocenę danego zagadnienia (np. planowania budżetu) przyczynia się do ujawnienia ewentualnych nieprawidłowości lub efektywniejszego gospodarowania posiadanymi przez jednostkę środkami finansowymi. Ponadto audyt przyczynia się do identyfikacji i ograniczania ryzyk oraz oszczędności np. poprzez zmniejszenie kosztów działania jednostki. ${ }^{14}$

Audytorzy swoje wyniki pracy (sprawozdanie $\mathrm{z}$ audytu) przedstawiają kierownikowi jednostki sektora finansów publicznych, który na jego podstawie podejmuje kluczowe decyzje w odniesieniu do badanego obszaru. ${ }^{15}$ Bardzo duża dynamika zmian jaka następuje w otoczeniu prawnym i gospodarczym jednostek sektora finansów publicznych sprawia, że audyt wewnętrzny staje się kluczowym instrumentem wsparcia kierowników jednostki, a jego działania przyczyniają się do poprawy gospodarki finansowej podmiotu.

\footnotetext{
${ }^{9}$ K. Czerwiński, Audyt wewnętrzny, InfoAudit Sp. z o.o., wyd. 1, Warszawa 2004 r., s. 60.

${ }^{10}$ R. Moeller, Nowoczesny audyt wewnętrzny, Wolters Kluwer Polska, Warszawa 2011 r., s. 47.

${ }_{11}$ T. Kiziukiewicz, H. Szymańska, Kontrola zarzqdcza $w$ jednostkach sektora finansów publicznych [w:] T. Kiziukiewicz (red.), Audyt wewnętrzny w strukturze kontroli zarzqdczej, Difin, Warszawa 2013 r., s. 40-44.

${ }^{12}$ Ustawa z dnia 27 sierpnia 2009 r. o finansach..., art. 68.

${ }^{13}$ L. Morrell, M. Kopanyi, Managing Local Expenditures [w:] C. Farvacque-Vitkovic, M. Kopanyi (red.), Municipal Finances. A Handbook for Local Governments, International Bank for Reconstruction and Development / The World Bank, Washington DC, 2014 r. s. 220.

${ }^{14} \mathrm{~K}$ H Spencer Pickett, The internal auditing handbook. Third edition, John Wiley \& Sons Ltd, West Sussex, United Kingdom, 2010 r., s. 179-182.

${ }^{15}$ H. Grocholski (red.), Praktyczne aspekty audytu wewnętrznego. Tom 1, Instytut Rachunkowości i Podatków, Warszawa 2004 r., s. 11-12.
} 


\section{Rola audytu wewnętrznego w ocenie wydatków na administrację publiczną w badanych samorządach miejskich}

Ponoszenie wydatków przez jednostkę sektora finansów publicznych jest jednym z kluczowych procesów realizowanych w ramach systemu finansów publicznych, który poddawany jest ocenie przez uprawnione do tego zewnętrzne organy kontroli jak również przez niezależnych audytorów wewnętrznych zatrudnionych w danej jednostce. Audytorzy wewnętrzni na podstawie prowadzonej analizy ryzyka wyznaczają obszary, które powinny być przez nich objęte niezależną oceną w jednostce. Wśród tych obszarów kluczowa jest gospodarka finansowa danej jednostki. Sektor finansów publicznych obejmuje bardzo dużo podmiotów, w tym również jednostki samorządu terytorialnego.

Poszczególne jednostki sektora finansów publicznych realizują swoje zadania w oparciu o środki finansowe gromadzone zgodnie $\mathrm{z}$ obowiązującymi przepisami prawa regulującymi m.in. ich dochody. Środki publiczne powinny być wykorzystywane efektywnie, skutecznie oraz zgodnie z ich przeznaczeniem określonym przepisami oraz decyzjami właściwych organów ustawodawczych lub uchwałodawczych. Zgodność ponoszenia wydatków z przepisami prawa jest w tym obszarze kluczowa. Ocena procesu gospodarowania i wydatkowania środków publicznych musi podlegać skutecznemu nadzorowi i audytowi przy jednoczesnym zdiagnozowaniu potencjalnych zagrożeń w tym obszarze. Należy podkreślić, że ,przeznaczanie środków publicznych na określone cele znajduje odzwierciedlenie $w$ wydatkach. Wydatkami publicznymi sa wydatki ponoszone na realizację zadań publicznych. Sa one ponoszone $w$ celu zaspokojenia potrzeb zbiorowych i częściowo potrzeb indywidualnych". ${ }^{16}$

Prawidłowe oszacowanie ryzyk związanych $\mathrm{z}$ niewłaściwym wydatkowaniem środków ma kluczowe znaczenie dla stabilności finansowej danej jednostki. Wynika to $\mathrm{z}$ konieczności równoważenia budżetu oraz racjonalnego wydatkowania środków przez samorządy na niezbędne cele i zadania wynikające $\mathrm{z}$ przepisów. W celu zapewnienia prawidłowego wydatkowania środków publicznych w sektorze finansów publicznych ustawodawca wprowadził przepisy o naruszeniu dyscypliny finansów publicznych. ${ }^{17}$ Katalog naruszeń dyscypliny finansów obejmuje również szereg przewinień związanych $\mathrm{z}$ nieprawidłowym wydatkowaniem środków publicznych. Zatem prowadzenie przez audytorów wewnętrznych oceny procesu wydatkowania przez jednostkę środków publicznych ma znaczenie z wielu względów, zarówno zarządczych jak i formalno - prawnych. Rola audytora w tym obszarze jest kluczowa, gdyż przeprowadzenie przez niego oceny procesu wydatkowania w wybranym zakresie, może przyczynić się do ustalenia potencjalnych zagrożeń i nieprawidłowości oraz do poprawy skuteczności działania poprzez wyeliminowanie stwierdzonych błędów w ocenianym obszarze. Ustalenie przez audytora wewnętrznego potencjalnego zagrożenia w badanym obszarze może umożliwić jego wyeliminowanie oraz uchronienie jednostki przed konsekwencjami związanymi ze zmaterializowaniem się tego ryzyka.

Rola audytu jest nie do przecenienia w procesie oceny gospodarki finansowej, gdyż badanie prawidłowości ponoszenia wydatków może przyczynić się do oszczędności lub

\footnotetext{
${ }^{16}$ M. Podstawka, Podstawy finansów. Teoria i praktyka, SGGW, wyd. 2, Warszawa, 2011 r. s. 62.

${ }^{17}$ Ustawa z dnia 17 grudnia 2004 r. o odpowiedzialności za naruszenie dyscypliny finansów publicznych, (tj. Dz. U. z 2018 r. poz. 1458).
} 
też uniknięcia niezasadnego wydatku z budżetu. Ponoszenie wydatków przez daną jednostkę sektora finansów publicznych niestety zazwyczaj nie obejmuje bardzo ważnej kwestii jaką jest ich efektywność. „W zasadzie wydatkowaniu publicznych środków pieniężnych w Polsce nie towarzyszy ocena efektywnościowa. Formalne kryteria owego wydatkowania zastępuja kryteria efektywności i racjonalności" ${ }^{18}$

Zadania jednostek samorządu terytorialnego szczebla gminnego obejmują zarówno zadania własne jak i zlecone (tj. zadania z zakresu administracji rządowej). ${ }^{19}$ Ponadto trzeba mieć na uwadze, że przyjęte rozwiązania organizacyjno - prawne w zakresie funkcjonowania administracji publicznej w Polsce sprawiły, że niektóre gminy miejskie są także powiatem (miastem na prawach powiatu) i wykonują również jego zadania. ${ }^{20}$ Oznacza to konieczność ponoszenia przez takie jednostki wydatków $\mathrm{z}$ tytułu wykonywania zadań przypisanych dla samorządu szczebla gminnego i powiatowego, co wymaga zwiększonego nadzoru i kontroli.

Realizacja audytu wewnętrznego w zakresie oceny procesu wydatkowania środków publicznych przez jednostkę może obejmować każdy z działów, rozdziałów lub też paragrafów ujętych w klasyfikacji budżetowej. Prowadzenie audytów w zakresie realizacji budżetu gminy wpisuje się bezpośrednio w system kontroli zarządczej, w którym audyt wewnętrzny pełni ważną funkcję monitorującą cały proces. Ponadto audyt wydatków, może poprawić gospodarkę finansową jednostki. Uzyskane podczas audytu informacje oraz przedstawiona ocena procesu gospodarowania środkami publicznymi może być podstawą do podjęcia działań naprawczych bądź ograniczenia lub też zaniechania nieuzasadnionych wydatków $\mathrm{z}$ budżetu. ${ }^{21}$

Podstawą do przeprowadzenia audytu wydatków jest analiza planu finansowego jednostki (budżetu miasta na prawach powiatu). Obejmuje ona ocenę procesu planowania wydatków oraz ich wykonania w danym roku budżetowym. Kluczowa jest weryfikacja zgodności ponoszonych wydatków z planem finansowym oraz analiza dokumentów finansowych i zapisów w systemach finansowo - księgowych jednostki. Ocenie podlega również system kontroli finansowej danego wydatku. W ramach tego audytorzy analizują proces opisywania dokumentów finansowych danego wydatku, zgodnie $\mathrm{z}$ obowiązująca $\mathrm{w}$ jednostce instrukcją obiegu dokumentów finansowo księgowych. Kluczowa jest również analiza sprawowania nadzoru nad wydatkami przez upoważnionych do tego pracowników jednostki. Ponadto ocenie podlega także zasadność danego wydatku. Stwierdzenie podczas audytu ewentualnych odstępstw od obowiązujących procedur i przepisów może świadczyć o braku skutecznych mechanizmów kontrolnych w tym zakresie. Poza tym bardzo ważne jest zidentyfikowanie oraz szacowanie potencjalnych ryzyk, stanowiących kluczowe zagrożenie jakim jest niezasadne wydatkowanie środków publicznych. Poza tym przy audycie wydatków konieczne jest również ustalenie, czy zachowano zasady budżetowe takie jak zasada równowagi, jawności, jedności, operatywności, jednorodności a przede

\footnotetext{
18 M. Podstawka, Nowoczesne zarzqdzanie wydatkami publicznymi, [w:] Polityki Europejskie, Finanse i Marketing, Nr 6 (55)/2011, SGGW, Warszawa, 2011 r., s. 89.

${ }^{19}$ Ustawa z dnia 8 marca 1990 r. o samorzqdzie gminnym (t.j. Dz. U. z 2019 r. poz. 506).

${ }^{20}$ Ustawa z dnia 5 czerwca 1998 r. o samorzadzie powiatowym (t.j. Dz. U. z 2019 r. poz. 511).

${ }^{21}$ D. E. Wildasin, Urban Public Finance, wyd. Routledge Taylor\&Francis Group, New York, 2012 r., s. $36-62$.
} 
wszystkim zupełności (powszechności), która „oznacza, iż $w$ budżecie uwzględnione powinny zostać wszystkie dochody $i$ wydatki". ${ }^{22}$

Większość wydatków z budżetu samorządu wynika z konieczności realizacji określonych zadań ustawowych. Świadczenie usług publicznych a zatem realizacja zadań samorządu wymaga ponoszenia wydatków na podległą jej administrację publiczną. Wydatki na funkcjonowanie administracji publicznej kształtują się na różnym poziomie, przede wszystkim w zależności od wielkości danej jednostki samorządu terytorialnego.

Tabela 1 zawiera ogólne zestawienie wybranych pozycji wydatków w dziale 750 - administracja publiczna dla 3 miast na prawach powiatu $\mathrm{z}$ województwa łódzkiego za lata 2013-2017, według danych na 31 grudnia danego roku.

Tabela 1. Wybrane pozycje wydatków $\mathrm{z}$ budżetów trzech miast na prawach powiatu $\mathrm{z}$ województwa łódzkiego za lata 2013-2017 w dziale 750 - administracja publiczna w zł wraz z dynamiką zmian (Łódź, Piotrków Trybunalski, Skierniewice)

\begin{tabular}{|c|c|c|c|c|c|c|}
\hline Lata & Łódź & $\begin{array}{l}\text { Piotrków } \\
\text { Trybunalski }\end{array}$ & Skierniewice & $\begin{array}{c}\text { Dynamika } \\
2013=100 \% \\
\text { m. Łódź }\end{array}$ & $\begin{array}{c}\text { Dynamika } \\
2013=100 \% \text { m. } \\
\text { Piotrków } \\
\text { Trybunalski }\end{array}$ & $\begin{array}{c}\text { Dynamika } \\
2013=100 \% \\
\text { m. Skierniewice }\end{array}$ \\
\hline \multicolumn{7}{|c|}{ Wydatki ogółem w zł } \\
\hline 2013 & 449591793 & 20009701 & 13934541 & $100 \%$ & $100 \%$ & $100 \%$ \\
\hline 2014 & 267034853 & 21374610 & 13723003 & $59 \%$ & $107 \%$ & $98 \%$ \\
\hline 2015 & 241724268 & 24819779 & 14582653 & $54 \%$ & $124 \%$ & $105 \%$ \\
\hline 2016 & 287422459 & 21490452 & 17107747 & $64 \%$ & $107 \%$ & $123 \%$ \\
\hline 2017 & 343817093 & 25866972 & 18895212 & $76 \%$ & $129 \%$ & $136 \%$ \\
\hline \multicolumn{7}{|c|}{ Wydatki bieżące ogółem w zł } \\
\hline 2013 & 179117773 & 19313636 & 13844990 & $100 \%$ & $100 \%$ & $100 \%$ \\
\hline 2014 & 177882238 & 19667949 & 13679129 & $99 \%$ & $102 \%$ & $99 \%$ \\
\hline 2015 & 204199210 & 20568174 & 14528462 & $115 \%$ & $106 \%$ & $105 \%$ \\
\hline 2016 & 189546936 & 20941306 & 16255023 & $106 \%$ & $108 \%$ & $117 \%$ \\
\hline 2017 & 230025588 & 24221119 & 18183040 & $128 \%$ & $125 \%$ & $131 \%$ \\
\hline \multicolumn{7}{|c|}{ Wydatki bieżące na wynagrodzenia w zł } \\
\hline 2013 & 90081211 & 12979032 & 7803156 & $100 \%$ & $100 \%$ & $100 \%$ \\
\hline 2014 & 92066782 & 13201959 & 8128889 & $102 \%$ & $102 \%$ & $104 \%$ \\
\hline 2015 & 93200625 & 13784480 & 8903330 & $103 \%$ & $106 \%$ & $114 \%$ \\
\hline 2016 & 95438248 & 14137805 & 10504174 & $106 \%$ & $109 \%$ & $135 \%$ \\
\hline 2017 & 105856552 & 16173738 & 11457492 & $118 \%$ & $125 \%$ & $147 \%$ \\
\hline \multicolumn{7}{|c|}{ Wydatki majątkowe ogółem w zł } \\
\hline 2013 & 270474019 & 696065 & 89551 & $100 \%$ & $100 \%$ & $100 \%$ \\
\hline 2014 & 89152615 & 1706660 & 43874 & $33 \%$ & $245 \%$ & $49 \%$ \\
\hline 2015 & 37525058 & 4251605 & 54191 & $14 \%$ & $611 \%$ & $61 \%$ \\
\hline 2016 & 97875523 & 549146 & 852724 & $36 \%$ & $79 \%$ & $952 \%$ \\
\hline 2017 & 113791506 & 1645853 & 712172 & $42 \%$ & $236 \%$ & $795 \%$ \\
\hline
\end{tabular}

Źródło: opracowanie własne na podstawie danych z Banku Danych Lokalnych Głównego Urzędu Statystycznego (data pobrania 19 maja 2019 r. https://bdl.stat.gov.pl/BDL/dane/podgrup/tablica) według stanu danych na dzień 16 maja 2019 r.

${ }^{22}$ M. Podstawka, Zasady budżetowania [w:] M. Podstawka (red.), Finanse, Instytucje. Instrumenty. Podmioty. Rynki. Regulacje., PWN, Warszawa, 2010 r. s. 121. 
Tabela 1 poza ogólnym zestawieniem ponoszonych wydatków na samorządową administrację publiczną przez wybrane jednostki zawiera informację o dynamice tych wydatków. W przypadku miasta Łodzi wyraźnie widać, że wydatki ogółem na administrację publiczną w poszczególnych latach 2014-2017 ulegały zmniejszeniu w odniesieniu do bazowego roku 2013 (w 2017 r. o 24\% w odniesieniu do 2013 r., tj. z 449.591.793 zł do 343.817.093 zł). Pomimo tego spadku wzrosły w Łodzi wydatki bieżące na wynagrodzenia pracowników (wzrost o 18\% w $2017 \mathrm{r}$. w odniesieniu do roku bazowego tj. 2013 tj. z 90.081 .211 zł w 2013 r. do 105.856 .552 zł w 2017 r.).

Odmienna sytuacja miała miejsce $\mathrm{w}$ przypadku dwóch pozostałych miast tj. Piotrkowa Trybunalskiego i Skierniewic, ponieważ wydatki ogólne na administrację publiczną rosły w poszczególnych latach w odniesieniu do roku 2013 (wyjątkiem był rok 2014, wtedy miasto Skierniewice zmniejszyły wydatki rok do roku o 2\%). Dodatkowo wzrost następował w poszczególnych kategoriach wydatków. Ponadto w przypadku miast Piotrków Trybunalski oraz Skierniewice w odróżnieniu od Łodzi zwiększono znacznie wydatki majątkowe w dziale 750 - administracja publiczna. Wynikało to $\mathrm{z}$ konieczności podejmowania przez kierowników jednostek działań mających na celu doposażenia sprzętowego pracowników urzędu oraz jednostek organizacyjnych poszczególnych miast. Konieczność realizacji nowych zadań przez samorządy skutkuje zwiększeniem wydatków na administracje. Przedmiotowe wydatki mogą być wynikiem zwiększenia zatrudnienia oraz potrzeby wyposażenia nowych pracowników w niezbędny sprzęt itd. Jednakże wzrost tych wydatków może być również spowodowany innymi czynnikami, które w trakcie audytu muszą być przedmiotem wnikliwej analizy.

\section{Audyt wewnętrzny wydatków w dziale 750 - administracja publiczna w jednostce samorządu terytorialnego}

Realizacja audytu wydatków na administrację publiczną obejmuje przede wszystkim analizę zasadności ponoszonych wydatków. Zasadniczą część wydatków związanych z administracją publiczną stanowią wydatki bieżące, w tym przede wszystkim na wynagrodzenia pracowników urzędu. Ponadto część środków przeznaczana jest na wydatki majątkowe związane m.in. z koniecznością wyposażenia pracowników w niezbędny sprzęt. Realizacja audytu wydatków w wybranym dziale wymaga analizy poszczególnych wydatków w zakresie ich zasadności oraz zgodności $\mathrm{Z}$ planem finansowym. Weryfikacja zasadności wydatku powoduje konieczność zapoznania się przez audytora z uzasadnieniem danego wydatku. Zgodnie z przyjętymi rozwiązaniami organizacyjnymi zadania audytu wewnętrznego w Urzędzie Miasta Piotrkowa Trybunalskiego realizuje audytor wewnętrzny z Biura Audytu Wewnętrznego i Kontroli. $^{23}$

Kluczową pozycję w wydatkach jednostki samorządu terytorialnego (w dziale - 750 na administracja publiczna) stanowią wydatki na wynagrodzenia pracowników. Zmiany $\mathrm{w}$ tej pozycji wydatków determinowane były rotacją pracowników oraz wzrostem wynagrodzeń. Na zmianę poziomu zatrudnienia wpływało nakładanie nowych zadań,

co każdorazowo potwierdzane jest w opisie / uzasadnieniu do danego wydatku. Podczas

${ }^{23} \mathrm{http}: / /$ www.bip.piotrkow.pl/index.php?idg=2\&id=1056\&x=36\&y=8\&z=17 [data pobrania $8.10 .2019 \mathrm{r}$.] 
audytu wydatków weryfikacja obejmuje ocenę wykonania danego wydatku z planem finansowym (planem budżetu wraz z jego zmianami) na dany rok oraz jego wpływ na budżet miasta. Na potrzeby niniejszej publikacji dokonano analizy wydatków w dziale - 750 na administracja publiczna) w mieście Piotrków Trybunalski (miasto na prawach powiatu w województwie łódzkim) za $2018 \mathrm{r}$. Do analizy wykorzystano informacje ze „Sprawozdania z realizacji budżetu Miasta Piotrkowa Trybunalskiego za 2018 r. ${ }^{24}$

W przypadku audytu wewnętrznego wydatków na administrację publiczną cele ogólne audytu obejmują przede wszystkim: ocenę zgodności poszczególnych wydatków $\mathrm{z}$ budżetu miasta $\mathrm{z}$ obowiązującymi przepisami oraz wewnętrznymi procedurami, ocenę zasadności poszczególnych wydatków pod kątem ich racjonalności oraz weryfikację funkcjonowania systemu kontroli zarządczej w badanym obszarze.

Tabela 2 Wydatki z budżetu Miasta Piotrkowa Trybunalskiego w 2018 według stanu na dzień 31 grudnia 2018 r. w rozdziale 750 - administracja publiczna wraz kwotą wydatków w zł na 1 mieszkańca oraz procentowym udziałem danego wydatku z rozdziału $750 \mathrm{w}$ ogólnej kwocie wydatków z budżetu w 2018 r.

\begin{tabular}{|c|c|c|c|c|}
\hline Lp. & $\begin{array}{c}\text { Wybrane wydatki z rozdziału } \\
750 \text { - administracja publiczna }\end{array}$ & $\begin{array}{c}\text { Wydatki w zł } \\
\text { z budżetu } \\
\text { miasta według } \\
\text { stanu } \\
\text { na } \\
31.12 .2018 \mathrm{r} .\end{array}$ & $\begin{array}{c}\text { Kwota wydatków w zł } \\
\text { na jednego mieszkańca } \\
\text { na dzień 31.12.2018 } \\
\text { (według stanu ludności } \\
\text { na 31.12.2018 r. } \\
-73670 \text { osób) }\end{array}$ & $\begin{array}{c}\text { \% udział danego } \\
\text { wydatku w ogólnej } \\
\text { kwocie wydatków } \\
\text { miasta w 2018 r. }\end{array}$ \\
\hline 1 & $\begin{array}{c}\text { wynagrodzenia wraz ze składkami } \\
\text { od nich naliczanymi }\end{array}$ & 20475160 & 278 & $4,34 \%$ \\
\hline 2 & $\begin{array}{c}\text { Wydatki bieżące związane z } \\
\text { realizacją ich zadań statutowych }\end{array}$ & 4763963 & 65 & $1,01 \%$ \\
\hline 3 & $\begin{array}{c}\text { Wydatki bieżące na świadczenia } \\
\text { na rzecz osób fizycznych }\end{array}$ & 413526 & $6,09 \%$ \\
\hline 4 & $\begin{array}{c}\text { Wydatki bieżące ogółem } \\
\text { (suma wierszy 1 - 3) }\end{array}$ & 25652649 & 648 & $5,44 \%$ \\
\hline 5 & $\begin{array}{c}\text { Wydatki majątkowe } \\
\text { (inwestycje i zakupy inwestycyjne) }\end{array}$ & 4458739 & 61 & $0,95 \%$ \\
\hline 6 & $\begin{array}{c}\text { Wydatki z budżetu ogółem } \\
\text { (suma wierszy 4 - 5) }\end{array}$ & 30111388 & 409 & $6,39 \%$ \\
\hline
\end{tabular}

Źródło: Opracowanie własne na podstawie Sprawozdania z wykonania budżetu Miasta Piotrkowa Trybunalskiego za 2018 r. oraz danych z Banku Danych Lokalnych Głównego Urzędu Statystycznego (https://bdl.stat.gov.pl/BDL/start).

Szczegółowe dane dotyczące poszczególnych wydatków zawierają sprawozdania finansowe (m.in. sprawozdanie $\mathrm{z}$ realizacji budżetu jednostki za dany rok). Podczas audytu niezbędna jest również analiza dokumentacji finansowej prowadzonej przez poszczególne komórki organizacyjne odpowiadające za gospodarowanie środkami budżetowymi (m.in. uzasadnienia merytoryczne wydatków). Kluczowe dane zawarto w tabeli 2, które obejmują wybrane informacje o wysokości poniesionych przez miasto Piotrków Trybunalski w 2018 r. wydatków w dziale 750 - administracja publiczna. Ponadto w tabeli ujęto również rozkład poszczególnych pozycji wydatków w 2018 r. na

24 Sprawozdanie $z$ wykonania budżetu Miasta Piotrkowa Trybunalskiego za $2018 \quad r$. - http://www.bip.piotrkow.pl/index.php?idg=3\&id=1843\&x=56\&y=2, data dostępu: [8 czerwca 2019 r.] 
administrację publiczną w przeliczeniu na 1 mieszkańca Piotrkowa Trybunalskiego ${ }^{25}$. Dodatkowo poniższa tabela przedstawia procentowy udział poszczególnych wydatków z budżetu miasta Piotrkowa Trybunalskiego w ogólnej kwocie wydatków poniesionych przez miasto w badanym roku, które wyniosły ogółem na 31 grudnia 2018 r. 471283 588 zł (przy ogólnej kwocie dochodów miasta - 432733130 zł (deficyt budżetu w wysokości 38550458 zł). ${ }^{26}$

Wydatki ogółem z budżetu miasta Piotrkowa Trybunalskiego na administrację publiczną w 2018 r. stanowiły łącznie 6,39\% ogólnej kwoty wydatków z budżetu, która wyniosła na dzień 31 grudnia 2018 r. 471.283 .588 zt. ${ }^{27}$ Wydatki bieżące na administrację publiczną stanowiły $85,19 \%$ ogólnej kwoty wydatków z budżetu miasta $\mathrm{w}$ 2018 r. Zgodnie $\mathrm{z}$ danymi tabeli 2 największe wydatki w 2018 r. w dziale 750 poniesiono na wynagrodzenia, tj. - $20.475 .160 \mathrm{zl}$, co stanowiło $4,34 \%$ wydatków ogółem. Wydatki majątkowe na administrację w 2018 r. wyniosły ogółem 4.458 .739 zł i stanowiły $0,95 \%$ ogółu wydatków z budżetu miasta. Analizując wydatki ogółem na administrację publiczną w Piotrkowie Trybunalskim (zgodnie $\mathrm{z}$ danymi $\mathrm{w}$ tabeli $1 \mathrm{i}$ tabeli 2) rok do roku (2017/2018), wzrosły one z 25.866.972 zł w 2017 r. do 30.111.388 zł w 2018 r. (wzrost wydatków o 4.244.416 zł). Oznacza to utrzymywanie się tendencji wzrostowej, którą wyraźnie widać w danych za lata 2013-2017 zawartych w tabeli 1 . Wskazuje to, że wydatki miasta Piotrkowa Trybunalskiego na bieżącą realizację zadań przez pracowników z każdym rokiem generują coraz większe koszty. Zaobserwowana tendencja wzrostowa powinna stanowić wskazówkę / zalecenie audytorów dla kierownictwa urzędu, aby dokonać dokładnej analizy potrzeb kadrowych jednostki w celu ewentualnego ograniczenia dynamiki wzrostu wydatków na wynagrodzenia w kolejnych latach.

Powyższe ustalenia związane są $\mathrm{z}$ potencjalnym ryzykiem utrzymywania $\mathrm{w}$ jednostce zatrudnienia pracowników na nieadekwatnym poziomie do liczby realizowanych zadań oraz realnego obciążenia praca poszczególnych stanowisk pracy. Ustalenie zasadności przedmiotowego wydatku na wynagrodzenia wymaga przeprowadzenia dodatkowych analiz związanych $\mathrm{z}$ oceną relacji poziomu zatrudnienia do realizowanych zadań. W związku z powyższym kolejne zalecenie $\mathrm{z}$ audytu wydatków powinno dotyczyć konieczności przeprowadzenia odrębnego zadania audytowego w zakresie oceny efektywności pracy poszczególnych pracowników.

Poza wydatkami bieżącymi na administrację, część środków przeznaczono na inwestycje. Wydatki miasta na inwestycje w rozdziale 750 stanowiły $14,81 \%$ ogólnej kwoty wydatków z budżetu w $2018 \mathrm{r}$. Wydatki inwestycyjne w analizowanym rozdziale 750 stanowiły łącznie 0,95\% ogólnej kwoty wydatków z budżetu miasta w 2018 r. Analiza poszczególnych wydatków w tym zakresie wykazała, że środki te przeznaczono m.in. na następujące zadania inwestycyjne:

$$
>\quad \text { zakup sprzętu komputerowego i oprogramowania - } 36900 \mathrm{zk} \text {, }
$$
system kolejkowy dla budynków Urzędu Miasta - 45315 zł,

\footnotetext{
$25 \mathrm{Na}$ podstawie danych $\mathrm{z}$ Banku Danych Lokalnych Głównego Urzędu Statystycznego https://bdl.stat.gov.pl/BDL/start [data dostępu: 8 czerwca 2019 r.] ogólna liczba mieszkańców miasta na dzień 31 grudnia 2018 r. wynosiła 73670 osób.

${ }^{26}$ Sprawozdanie z wykonania budżetu Miasta Piotrkowa Trybunalskiego za 2018 r. - kwoty wydatków zostały zaokraglone do pełnych złotych.

${ }^{27}$ Sprawozdanie z wykonania budżetu Miasta Piotrkowa Trybunalskiego za 2018 r.
} 
$4342048 \mathrm{zt}^{28}$

termomodernizacja i adaptacja budynku na potrzeby Urzędu Miasta -

Poszczególne wydatki inwestycyjne zostały zrealizowane z planem budżetu na 2018 r., zatem były ujęte $\mathrm{w}$ pierwotnym planie finansowym jednostki. Zgodnie z powyższymi danymi wydatki inwestycyjne w rozdziale 750 stanowiły niewielki udział w ogólnych wydatkach (poniżej 1\%). Zatem można stwierdzić, że kluczowym wydatkiem na funkcjonowanie administracji są koszty osobowe. Poszczególne wydatki były realizowane według procedury obiegu i kontroli dokumentów finansowo księgowych. ${ }^{29}$ Stwierdzenie $\mathrm{w}$ trakcie audytu ewentualnych odstępstw od procedury może skutkować np. naruszeniem przepisów w tym dyscypliny finansów publicznych. Ponadto stwarza to poważne zagrożenie nieprawidłowego wydatkowania środków $\mathrm{z}$ budżetu miasta.

Przeprowadzona analiza wydatków $\mathrm{z}$ budżetu na administrację publiczną uwidoczniła, że niezależny audyt wydatków jest niezbędny dla racjonalizacji wydatków w odniesieniu do pozostałych działów budżetu. Kompleksowy audyt wszystkich wydatków urzędu w tym zakresie byłby przydatny, gdyż mógłby przyczynić się do zracjonalizowania wydatków całej jednostki. Skuteczniejsze gospodarowanie wydatkami publicznymi byłoby pożądane szczególnie w obszarze wydatków bieżących na wynagrodzenia, które stanowią największą pozycję w wydatkach w dziale 750 i dynamicznie wzrastały w poszczególnych latach (tabela 1) objętych badaniem.

Audytowanie wydatków samorządów lokalnych jest standardem w państwach demokratycznych. Ich zakres, cele oraz podmioty uprawnione do audytu określa prawo danego państwa. Przykładowo National Audit Office jako uprawniony podmiot przeprowadza audyty wydatków władz lokalnych w Wielkiej Brytanii. Przedstawiane raporty z audytów potwierdzają, że monitorowanie wydatków publicznych jest niezbędne do sprawnego zarządzania finansami samorządów lokalnych. ${ }^{30}$ Audyt wydatków budżetowych, w tym na administrację publiczną prowadzi również Unia Europejska. Analizy wydatków przedstawiane w raportach Unii Europejskiej dotyczą wszystkich państw członkowskich ogółem jak i każdego państwa odrębnie. Aktualne dane z 2019 r. dotyczące wydatków Unii Europejskiej w okresie programowania 20142020 za lata 2014-2018 dowodza, że wydatki na administrację publiczną ogółem mają tendencję wzrostową, gdyż wzrosły z 9.656,2 mln Euro w 2017 r. do 9.943,5 mln Euro w 2018 r. $^{31}$

Mając powyższe na uwadze można stwierdzić, że audyt wydatków samorządu terytorialnego $\mathrm{w}$ Polsce niezależnie od zakresu lub obszaru jakiego dotyczy jest $\mathrm{w}$ pewnym zakresie tożsamy $\mathrm{z}$ działaniami podejmowanymi $\mathrm{w}$ krajach Unii Europejskiej. Wynika to w dużej mierze $\mathrm{z}$ faktu, że metodyka audytu prowadzonego $\mathrm{w}$ Polsce opiera się na sprawdzonych światowych rozwiązaniach w tym zakresie a problem ograniczania i racjonalizacji wydatków ogółem dotyczy większości państw na świecie.

\footnotetext{
${ }^{28}$ Sprawozdanie z wykonania budżetu Miasta Piotrkowa Trybunalskiego za 2018 r.

29 Zarzadzenie Nr 230 Prezydenta Miasta Piotrkowa Trybunalskiego z dnia 1 czerwca $2017 \quad r$ w sprawie wprowadzenia instrukcji obiegu i kontroli dokumentów finansowo - księgowych ze zm. (dostęp 2 czerwca 2019 r. - http://www.bip.piotrkow.pl/upload/20170602131058zxysva9ffl1u.pdf

${ }^{30} \mathrm{https}$ ://www.nao.org.uk/report/local-authority-governance-2/ - dostęp [26.11.2019 r.].

${ }^{31} \mathrm{https}: / /$ ec.europa.eu/budget/graphs/revenue_expediture.html - dostęp [26.11.2019 r.].
} 


\section{Podsumowanie}

Przedmiotem badania był audyt wydatków budżetowych w wybranych miastach na prawach powiatu $\mathrm{w}$ dziale 750 administracja publiczna. Przeprowadzenie audytu wydatków pozwoliło stwierdzić, że w 2 z 3 analizowanych miast wystapiła dynamika wzrostu ogólnych wydatków z budżetu na administrację publiczną (w latach 20132017). W każdym z 3 analizowanych miast nastąił wzrost wydatków na wynagrodzenia pracowników ogółem. Ponadto szczegółowa analiza wydatków za 2018 r. w Piotrkowie Trybunalskim wskazała, że wzrost wydatków w ocenianym dziale - 750 ma tendencję wzrostową, gdyż zwiększył się o 4.244 .416 zł w stosunku do wydatków w roku 2017 r.

Audyt wydatków w dziale 750 wykazuje, że właściwym byłoby przeprowadzenie kompleksowego audytu wydatków, a wnioski z niego mogłyby przyczynić się do zrównoważenia budżetu miasta Piotrkowa Trybunalskiego, którego deficyt w $2018 \mathrm{r}$. wyniósł ogółem $38.550 .458,10$ zł. Istotnym ograniczeniem w przeprowadzonych badaniach był brak dostępu do szczegółowych danych $\mathrm{z}$ systemów finansowo - księgowych ocenianych jednostek samorządu, które zawierają uzasadnienia danego wydatku. Dostęp do tych danych umożliwiłby pełniejszą analizę badanego obszaru.

Przeprowadzona analiza wydatków $\mathrm{z}$ budżetu samorządu miejskiego jest przykładem możliwości wykorzystania audytu wewnętrznego jako narzędzia racjonalizacji wydatków danej jednostki sektora finansów publicznych. Audyt wydatków jest zatem ważnym instrumentem przyczyniającym się do usprawnienia gospodarki finansowej danej jednostki a przez to całego sektora finansów publicznych.

\section{Bibliografia}

Czerwiński K., Audyt wewnętrzny, InfoAudit Sp. z o.o., wyd. 1, Warszawa 2004 r.,

M. Dylewski, B. Filipiak, M. Gorzałczyńska-Koczkodaj, Finanse samorzqdowe. Narzędzia, decyzje, procesy, PWN, Warszawa $2006 \mathrm{r}$.

C. Farvacque-Vitkovic, M. Kopanyi (red.), Municipal Finances. A Handbook for Local Governments, International Bank for Reconstruction and Development / The World Bank, Washington DC, $2014 \mathrm{r}$.

M. Gazda, O procesie racjonalizacji wydatków publicznych, Ruch Prawniczy, Ekonomiczny i Socjologiczny, VOL 78, NR 1 (2016), Uniwersytet Adama Mickiewicza w Poznaniu, s. 169-179. Grocholski H. (red.), Praktyczne aspekty audytu wewnętrznego. Tom 1, Instytut Rachunkowości i Podatków, Warszawa 2004 r.

Głuchowski, J., Pomorska, A., Szołno-Koguc, J. (red.), Ekonomiczne i prawne problemy racjonalizacji wydatków publicznych, Tom 1: Racjonalizacja wydatków publicznych uwarunkowania i instrumenty, Uniwersytet Marii Curie - Skłodowskiej, Lublin, 2005 r.

Kiziukiewicz T.(red.), Audyt wewnętrzny w strukturze kontroli zarzqdczej, Difin, Warszawa, 2013r.

Moeller Robert, Nowoczesny audyt wewnętrzny, Wolters Kluwer Polska, Warszawa 2011 r.

J. Pfaff, Rewizja finansowa, Uniwersytet Ekonomiczny w Katowicach, $2011 \mathrm{r}$.

Pickett K. H. Spencer, The internal auditing handbook. Third edition, John Wiley \& Sons Ltd, West Sussex, United Kingdom, 2010 r.

M. Podstawka, Podstawy finansów. Teoria i praktyka, SGGW, wyd. 2, Warszawa, $2011 \mathrm{r}$.

M. Podstawka, Nowoczesne zarzadzanie wydatkami publicznymi, [w:] Polityki Europejskie, Finanse i Marketing, Nr 6 (55)/2011, SGGW, Warszawa, 2011 r.

M. Podstawka, Zasady budżetowania [w:] M. Podstawka (red.), Finanse, Instytucje. Instrumenty. Podmioty. Rynki. Regulacje., PWN, Warszawa, 2010 r. 
Stiglitz J. E., Ekonomia sektora publicznego, PWN, Warszawa 2004 r.

D. E. Wildasin, Urban Public Finance, wyd. Routledge Taylor\&Francis Group, New York, 2012 r.

A. Żabka, Efficiency of budget expenditure inthe process of creating framework conditions for local development. Planing and evaluation, Wyższa Szkoła Finansów i Prawa, Bielsko - Biała, $2017 \mathrm{r}$.

Rozporzqdzenie Ministra Finansów z dnia 4 września 2015 r. w sprawie audytu wewnętrznego oraz informacji o pracy $i$ wynikach tego audytu, (tj. Dz. U. z 2018 r., poz. 506).

Ustawa z dnia 27 sierpnia 2009 r. o finansach publicznych, tj. (Dz. U. z 2019 r., poz. 869).

Ustawa z dnia 17 grudnia 2004 r. o odpowiedzialności za naruszenie dyscypliny finansów publicznych, (t.j. Dz. U. z 2018 r. poz. 1458).

Ustawa z dnia 14 lutego 2003 r. o rachunkowości (Dz.U. 2003, nr 49, poz. 408).

Ustawa z dnia 8 marca 1990 r. o samorzqdzie gminnym (t.j. Dz. U. z 2019 r. poz. 506).

Ustawa z dnia 5 czerwca 1998 r. o samorzqdzie powiatowym (t.j. Dz. U. z 2019 r. poz. 511).

Sprawozdanie z wykonania budżetu Miasta Piotrkowa Trybunalskiego za 2018 r. dostęp: [8 czerwca 2019 r.] - http://www.bip.piotrkow.pl/index.php?idg=3\&id=1843\&x=56\&y=2).

Zarzqdzenie Nr 230 Prezydenta Miasta Piotrkowa Trybunalskiego z dnia 1 czerwca 2017 r. w sprawie wprowadzenia instrukcji obiegu i kontroli dokumentów finansowo - księgowych ze zm. Dostęp [2 $\quad 2019$

http://www.bip.piotrkow.pl/upload/20170602131058zxysva9ffl1u.pdf

Bank Danych Lokalnych - https://bdl.stat.gov.pl/BDL/start.

http://www.bip.piotrkow.pl/index.php?idg=2\&id $=1056 \& \mathrm{x}=36 \& \mathrm{y}=8 \& \mathrm{z}=17$ dostęp [8.10.2019 r.].

https://www.nao.org.uk/report/local-authority-governance-2/ - dostęp [26.11.2019 r.].

https://ec.europa.eu/budget/graphs/revenue_expediture.html - dostęp [26.11.2019 r.].

\section{Summary}

The article presents the role and tasks of internal audit in the assessment of public expenditures in a selected area for municipal governments in Łódź, Piotrków Trybunalski and Skierniewice in Poland. The research found, among other things, that internal audits contribute to a more rational spending of funds from the city budget on public administration activities. In addition, it has also been shown that internal audit is a helpful tool in ensuring reasonable expenses for public finance sector entities. The assessment and monitoring of expenses is the responsibility of public authorities, to ensure rational financial management of a given local government unit.

The aim of the article is to present internal audit as an important tool to support city authorities in assessing the expenditure of municipalities in a selected area. For the purposes of this publication, local government units from the Łódź Voivodeship, i.e. a city with district status, were selected as an example for analysis. In this article, case study, analytical method, inference method and document examination method were used as research methods. To make the necessary analyses, materials made available by the surveyed entities and data available in public registers collected by authorized institutions were used.

Key words: internal audit, expenses, public sector, local government units, Poland JEL Codes: H-72, H-83

Informacja o autorze:

Dr Cezary Szydłowski

University of Łódz

Faculty of Economics and Sociology,

Department of Finance and Accounting SME

e-mail: cezary.szydlowski@uni.lodz.pl

ORCID: 0000-0002-7454-2908 